\title{
Inclusions of Silicate and Sulfate Melts in Chrome Diopside from the Inagli Deposit, Yakutia, Russia
}

\author{
V. B. Naumov ${ }^{a}$, V. S. Kamenetsky ${ }^{b}$, R. Thomas ${ }^{c}$, N. N. Kononkova ${ }^{a}$, and B. N. Ryzhenko ${ }^{a}$ \\ ${ }^{a}$ Vernadsky Institute of Geochemistry and Analytical Chemistry, Russian Academy of Sciences, \\ ul. Kosygina 19, Moscow, 119991 Russia \\ e-mail:naumov@geokhi.ru \\ ${ }^{b}$ School of Earth Sciences and Centre for Ore Deposit Research, University of Tasmania, Hobart, Australia \\ e-mail: Dima.Kamenetsky@utas.edu.au \\ ${ }^{c}$ GeoForschungsZentrum, Potsdam, Telegrafenberg B120, Potsdam, D-14473, Germany \\ e-mail: thomas@gfz-potsdam.de \\ Received April 17, 2007
}

\begin{abstract}
Melt inclusions were studied in chrome diopside from the Inagli deposit of gemstones in the Inagli massif of alkaline ultrabasic rocks of potassic affinity in the northwestern Aldan shield, Yakutia, Russia. The chrome diopside is highly transparent and has an intense green color. Its $\mathrm{Cr}_{2} \mathrm{O}_{3}$ content varies from 0.13 to $0.75 \mathrm{wt} \%$. Primary and primary-secondary polyphase inclusions in chrome diopside are dominated by crystal phases (80-90 vol \%) and contain aqueous solution and a gas phase. Using electron microprobe analysis and Raman spectroscopy, the following crystalline phases were identified. Silicate minerals are represented by potassium feldspar, pectolite $\left[\mathrm{NaCa}_{2} \mathrm{Si}_{3} \mathrm{O}_{8}(\mathrm{OH})\right]$, and phlogopite. The most abundant minerals in the majority of inclusions are sulfates: glaserite (aphthitalite) $\left[\mathrm{K}_{3} \mathrm{Na}\left(\mathrm{SO}_{4}\right)_{2}\right]$, glauberite $\left[\mathrm{Na}_{2} \mathrm{Ca}\left(\mathrm{SO}_{4}\right)_{2}\right]$, aluminum sulfate, anhydrite $\left(\mathrm{CaSO}_{4}\right)$, gypsum $\left(\mathrm{CaSO}_{4} \times 2 \mathrm{H}_{2} \mathrm{O}\right)$, barite $\left(\mathrm{BaSO}_{4}\right)$, bloedite $\left[\mathrm{Na}_{2} \mathrm{Mg}\left(\mathrm{SO}_{4}\right)_{2} \times 4 \mathrm{H}_{2} \mathrm{O}\right]$, thenardite $\left(\mathrm{Na}_{2} \mathrm{SO}_{4}\right)$, polyhalite $\left[\mathrm{K}_{2} \mathrm{Ca}_{2} \mathrm{Mg}\left(\mathrm{SO}_{4}\right)_{4} \times 2 \mathrm{H}_{2} \mathrm{O}\right]$, arcanite $\left(\mathrm{K}_{2} \mathrm{SO}_{4}\right)$, and celestite $\left(\mathrm{SrSO}_{4}\right)$. In addition, apatite was detected in some inclusions. Chlorides are probably present among small crystalline phases, because some analyses of aggregates of silicate and sulfate minerals showed up to $0.19-10.3 \mathrm{wt} \% \mathrm{Cl}$. Hydrogen was identified in the gas phase of polyphase inclusions by Raman spectroscopy. The composition of melt from which the chrome diopside crystallized was calculated on the basis of the investigation of silicate melt inclusions. This melt contains 53.5 wt $\% \mathrm{SiO}_{2}$, considerable amounts of $\mathrm{CaO}$ (16.3 wt \%), $\mathrm{K}_{2} \mathrm{O}\left(7.9\right.$ wt \%), $\mathrm{Na}_{2} \mathrm{O}(3.5$ wt \%), and $\mathrm{SO}_{3}(1.4 \mathrm{wt} \%)$ and moderate amounts of $\mathrm{Al}_{2} \mathrm{O}_{3}(7.5 \mathrm{wt} \%), \mathrm{MgO}(5.8 \mathrm{wt} \%), \mathrm{FeO}(1.1 \mathrm{wt} \%)$, and $\mathrm{H}_{2} \mathrm{O}$ (0.75 wt \%). The content of $\mathrm{Cr}_{2} \mathrm{O}_{3}$ in the melt was $0.13 \mathrm{wt} \%$. Many inclusions were homogenized at $770-850^{\circ} \mathrm{C}$, when all of the crystals and the gas phase were dissolved. The material of inclusions heated up to the homogenization temperature became heterogeneous even during very fast quenching (two seconds) producing numerous small crystals. This fact implies that most of the inclusions contained a salt (rather than silicate) melt of sulfate-dominated composition. Such inclusions were formed from salt globules (with a density of about $\left.2.5 \mathrm{~g} / \mathrm{cm}^{3}\right)$ occurring as an emulsion in the denser $\left(2.6 \mathrm{~g} / \mathrm{cm}^{3}\right)$ silicate melt from which the chrome diopside crystallized.
\end{abstract}

DOI: $10.1134 / \mathrm{S} 0016702908060025$

\section{INTRODUCTION}

The Inagli deposit of chrome diopside is located $30 \mathrm{~km}$ west of the city of Aldan (Yakutia, Russia), within the Inagli massif of alkaline ultramafic rocks of the potassic series [1-4]. The massif is situated in the northwestern margin of the Aldan shield. It is about $20 \mathrm{~km}^{2}$ in area and is topographically manifested as a cupola structure with a central caldera. It is nearly isometric in shape and has a concentrically zoned structure. The central part of the massif is a stock, $16 \mathrm{~km}^{2}$ in area, made up of forsterite dunite. The stock is surrounded by alkali gabbroids and pulaskites. The gabbroids are mainly shonkinites grading into mica-bearing pyroxenites. The pulaskites are accompanied by alkaline pegmatites, which occur mainly among the dunites and are less common in the zone of shonkinites. Sheet intrusions of syenite porphyry occur at the periphery of the massif within the Cambrian carbonate sequence.

The structure of the Inagli massif is controlled by a series of fault systems, the most important among which are large faults extending beyond the massif, as well as external and internal ring faults and a system of conical faults [3]. The external ring fault at the boundary of the dunite stock controls the exposures of shonkinite-pulaskite rocks. The fault was active during the development of the massif. An internal fault is distinguished in the western part of the massif on the basis of 
Table 1. Representative analyses (wt \%) of chrome diopside from the Inagli deposit

\begin{tabular}{|c|c|c|c|c|c|c|c|c|c|c|c|c|}
\hline \multirow{2}{*}{$\begin{array}{c}\text { Compo- } \\
\text { nent }\end{array}$} & \multicolumn{2}{|c|}{1} & \multicolumn{2}{|c|}{2} & \multicolumn{2}{|c|}{3} & \multicolumn{2}{|c|}{4} & \multicolumn{2}{|c|}{5} & \multicolumn{2}{|c|}{6} \\
\hline & core & rim & core & rim & core & rim & core & rim & core & rim & core & rim \\
\hline $\mathrm{SiO}_{2}$ & 57.00 & 55.68 & 55.81 & 56.35 & 54.48 & 56.03 & 56.04 & 56.20 & 56.73 & 56.05 & 55.14 & 54.38 \\
\hline $\mathrm{TiO}_{2}$ & 0.07 & 0.04 & 0.06 & 0.07 & 0.07 & 0.08 & 0.05 & 0.07 & 0.18 & 0.21 & 0.28 & 0.33 \\
\hline $\mathrm{Al}_{2} \mathrm{O}_{3}$ & 0.18 & 0.21 & 0.17 & 0.14 & 0.20 & 0.20 & 0.16 & 0.17 & 0.28 & 0.27 & 0.50 & 0.69 \\
\hline $\mathrm{FeO}$ & 1.21 & 1.20 & 1.12 & 1.21 & 1.21 & 1.25 & 1.16 & 1.31 & 1.92 & 1.92 & 2.77 & 3.39 \\
\hline $\mathrm{MnO}$ & 0.09 & 0.10 & 0.04 & 0.00 & 0.06 & 0.02 & 0.00 & 0.04 & 0.07 & 0.13 & 0.05 & 0.02 \\
\hline $\mathrm{MgO}$ & 17.92 & 17.66 & 18.01 & 17.78 & 17.81 & 18.36 & 17.85 & 17.74 & 17.40 & 17.32 & 17.09 & 16.77 \\
\hline $\mathrm{CaO}$ & 24.27 & 24.27 & 24.14 & 24.25 & 23.99 & 24.15 & 24.16 & 23.90 & 24.05 & 23.99 & 24.37 & 23.92 \\
\hline $\mathrm{Na}_{2} \mathrm{O}$ & 0.30 & 0.30 & 0.35 & 0.30 & 0.29 & 0.28 & 0.26 & 0.27 & 0.22 & 0.26 & 0.24 & 0.21 \\
\hline $\mathrm{Cr}_{2} \mathrm{O}_{3}$ & 0.27 & 0.51 & 0.29 & 0.40 & 0.28 & 0.25 & 0.21 & 0.17 & 0.13 & 0.13 & 0.25 & 0.13 \\
\hline $\mathrm{V}_{2} \mathrm{O}_{3}$ & 0.05 & 0.02 & 0.03 & 0.00 & 0.00 & 0.10 & 0.05 & 0.03 & 0.10 & 0.03 & 0.03 & 0.07 \\
\hline Total & 101.36 & 99.98 & 100.01 & 100.51 & 98.39 & 100.72 & 99.94 & 99.89 & 101.09 & 100.30 & 100.70 & 99.90 \\
\hline
\end{tabular}

Note: $(1,2)$ Green diopside, $(3,4)$ bluish green diopside, and $(5,6)$ brownish green diopside.

extensive fracturing, brecciation, and concentration of vein structures. The fault attenuates in the north and east.

The major units of the geologic structure of the deposit are the country dunites and the main sources of gemstones, pegmatites and feldspar-chrome diopsidephlogopite metasomatic rocks [3]. The dunites are characterized by almost horizontal fracture patterns, which give the appearance of schistosity. The dunites have the following mineral composition (\%): 40-85 olivine, 15-60 serpentine, 0.5-3.0 chrome spinel, 0.3-3.0 chrome diopside, 0.3-3.0 phlogopite, and 0.1-3.0 magnetite. Fresh dunites from the core of the massif are composed of forsterite with $2-11 \%$ of the fayalite component and chrome spinel. Serpentinized varieties contain also serpentine and magnetite. Metasomatically altered dunites contain ferromagnesian micas (mainly phlogopite) and chrome diopside [3].

The dunites host numerous pegmatite veins composed of early chrome diopside-bearing and late amphibole-feldspar varieties. The pegmatites form complex branching veins with apophyses and swells. Their morphology is controlled by the physical properties of the country rocks: in fractured zones, pegmatite bodies show abrupt inflections and wedgelike pinching out of individual branches. The contacts of pegmatites with the country rocks dip at angles from $30^{\circ}$ to $60^{\circ}$ and flatten with increasing depth to $20^{\circ}$ [3].

The deposit contains ten chrome diopside-bearing vein zones, among which only one is of economic importance. The zone consisting of chrome diopsidephlogopite-orthoclase rocks was tracked and contoured by open-cut and underground workings and explored by drilling to a depth of $50 \mathrm{~m}$. It is about $600 \mathrm{~m}$ long, and its thickness ranges from 5 to $115 \mathrm{~m}$ averaging $60 \mathrm{~m}$. The content of chrome diopside in this zone varies from a few percent to $100 \%$. Chrome diop- side crystals may be up to $20-50 \mathrm{~cm}$ across. They are divided by fractures into defect-free domains, from a few millimeters to $2-3 \mathrm{~cm}$ across. The chrome diopside is very transparent and has an intense green color. Zoned crystals were observed at the contact with the dunites. They consist of dark brown cores, yellowish green intermediate zones, and intense green margins. The chemical compositions of various chrome diopside crystals are given in Table 1 . The content of $\mathrm{Cr}_{2} \mathrm{O}_{3}$ in these crystals is $0.13-0.51 \mathrm{wt} \%$ with a maximum value of $0.75 \mathrm{wt} \%$.

The formation conditions and the chemical compositions of the parent medium from which chrome diopside crystallized are still unknown. The earliest data on the homogenization temperatures of polyphase (with numerous crystals) inclusions in diopside were reported in 1971 [5]. The temperatures appeared to be fairly high, $770-850^{\circ} \mathrm{C}$. It was also found that the homogeneous phase in the heated inclusions did not remain homogeneous after even very rapid (two-second) quenching. The inclusions were always heterogenized with the formation of numerous tiny crystals. These observations suggested that the homogeneous phase in the inclusions was not a silicate liquid, which would have produced a quench glass, but a salt melt. However, no methods were available at that time for the analysis of crystal phases in the inclusions and estimation of the composition of the mineral-forming medium. During the following years, local analytical methods (electron, ion, and proton microprobe; microRaman spectroscopy; etc.) have been developed and become accessible. This provided an opportunity to reinvestigate the inclusions in chrome diopside samples from the Inagli massif by means of various modern techniques. Such investigations allowed us to reveal the coexistence of silicate melts and immiscible globules of 

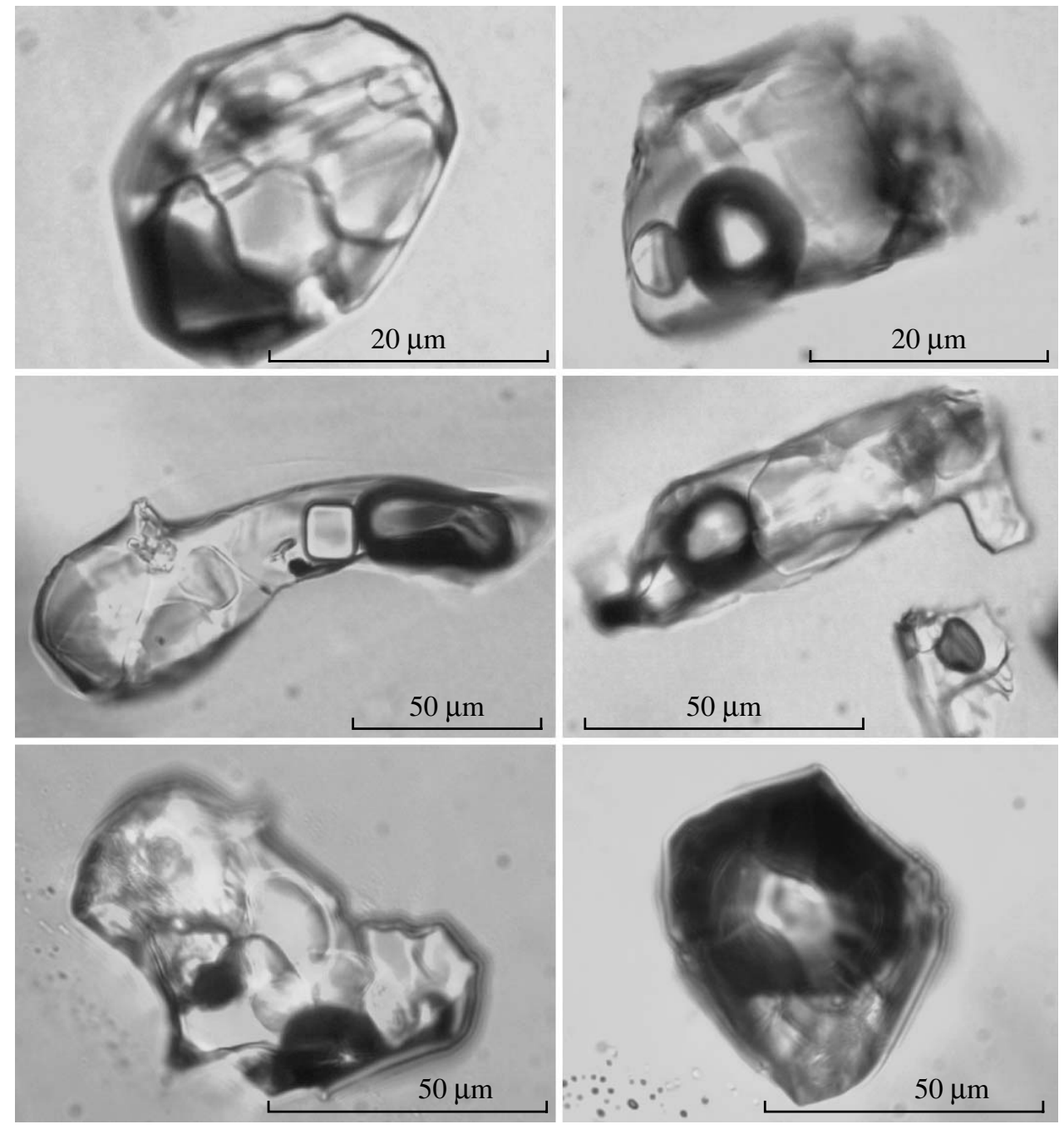

Fig. 1. Polyphase melt inclusions in chrome diopside from the Inagli deposit.

sulfate salt melts, which provided a better insight into the formation conditions of chrome diopside.

\section{INVESTIGATION OF INCLUSIONS IN CHROME DIOPSIDE}

Methods of the Investigation of Crystal and Gas Phases in Inclusions chrome diopside crystals with polyphase inclusions were polished until the inclusions were exposed on the surface and then analyzed using Camebax Microbeam and Cameca SX-100 electron microprobes (Vernadsky Institute of Geochemistry and Analytical Chemistry, Russian Academy of Sciences, Moscow, Russia) under the following conditions: an accelerating voltage of $15 \mathrm{kV}$, a beam current of $30 \mathrm{nA}$, and rastering over an area of $2 \times 2 \mu \mathrm{m}$. The accuracy of element analysis was $2 \%$ relative at contents of $>10 \mathrm{wt} \%$, $5 \%$ relative at $5-10 \mathrm{wt} \%$, and $10 \%$ relative at $<5 \mathrm{wt} \%$. In addition, crystal and gas phases from inclusions were investigated by Raman spectroscopy at the GeoFors-
chungsZentrum, Potsdam, Germany (Dilor XY Laser Raman Triple 800 spectrometer operating at a wavelength of $488 \mathrm{~nm}$ and a power of $450 \mathrm{~mW}$ ).

Results of Inclusion Investigation as was noted above, the numerous inclusions in chrome diopside are polyphase. Their size ranges from a few to $70-100 \mu \mathrm{m}$, and the majority of inclusions measure a few tens of micrometers. The inclusions are composed of numerous crystal phases accounting for 80-90 vol \%, interstitial aqueous solution between the crystal phases, and a gas phase (Fig. 1). Inclusions dominated by the gas phase were occasionally found. Crystals and aqueous solution account for a small and variable fraction of the volume of such inclusions (Fig. 1), which suggests a heterogeneous state of the mineral-forming medium. Most of the crystals in the inclusions are unisotropic and show different birefringence. The inclusions can be subdivided into two types on the basis of their distribution in chrome diopside. The first type includes isolated inclusions not related to any fractures; they can be 
unambiguously interpreted as primary. Inclusions of the second type have the same phase and chemical compositions but occur along healed fractures. We consider them as primary-secondary inclusions (after the classification of Ermakov [6]). Primary-secondary inclusions are most common in the chrome diopside.

The visual observation of inclusions in a microscopic heating stage showed that crystal dissolution begins at low temperatures of $150-200^{\circ} \mathrm{C}$. A further increase in temperature (Fig. 2) is accompanied by the dissolution of most crystals and a decrease in the volume of the gas phase. In the inclusions shown in Fig. 2, the gas phase disappeared at $615^{\circ} \mathrm{C}$, but some crystals were still present. The cooling of the inclusion resulted in the reappearance of the gas phase and growth of small crystals.

The following silicate minerals were identified by electron microprobe analysis: potassium feldspar, phlogopite, and pectolite. Their chemical compositions are shown in Table 2 . The daughter phlogopite crystals contain from 0.03 to 0.53 wt $\% \mathrm{Cr}_{2} \mathrm{O}_{3}$ (averaging $0.31 \mathrm{wt} \%$ ) and $0.01-0.68 \mathrm{wt} \% \mathrm{BaO}$ (averaging $0.28 \mathrm{wt} \%$ ). As the total of analyzed components in phlogopites was on average 95.7 wt \%, it can be supposed that they contain $\sim 4$ wt $\% \mathrm{H}_{2} \mathrm{O}$. Among other volatile components, $\mathrm{F}(0.20 \mathrm{wt} \%)$ and $\mathrm{Cl}(0.05 \%)$ were determined. Figure 3 shows a photomicrograph of one of such inclusions. It can be seen that the section exposed on the surface of chrome diopside and investigated with the electron microprobe is dominated by potassium feldspar and pectolite. In addition, two apatite crystals and potassium sulfate (arcanite) were detected in this section.

In addition to silicates, a number of sulfate minerals were detected in the polyphase inclusions. It should be noted that many polyphase inclusions contained only sulfate minerals and were free of silicates. In contrast, if a silicate mineral was present in an inclusion, sulfate minerals were also always detected. The electron microprobe analyses of the sulfate minerals are shown in Table 3. The potassium-sodium sulfate glaserite (aphthitalite) $\left[\mathrm{K}_{3} \mathrm{Na}\left(\mathrm{SO}_{4}\right)_{2}\right]$ is widespread; more rare are the potassium sulfate arcanite $\left(\mathrm{K}_{2} \mathrm{SO}_{4}\right)$, the sodium sulfate thenardite $\left(\mathrm{Na}_{2} \mathrm{SO}_{4}\right)$, the sodium-calcium sulfate glauberite $\left[\mathrm{Na}_{2} \mathrm{Ca}\left(\mathrm{SO}_{4}\right)_{2}\right]$, and a calcium-sodium sulfate (Table 3 , analysis 12 ). The crystals exposed on the surface are sometimes very small, and the obtained analyses may reflect the chemical composition of a mixture of various minerals. Table 3 presents several examples of such analyses (nos. 13-15), which indicate the presence of chlorides among the crystal phases, because the analyses show $0.9-10.3 \mathrm{wt} \% \mathrm{Cl}$. In addition to sulfate minerals, the inclusions contain apatite with high $\mathrm{SrO}(8.3-12.7$ wt \%) and a small admixture of $\mathrm{BaO}(0.16-0.41$ wt \%).

As was noted above, Raman spectroscopy was also used for the identification of crystal phases in the inclusions. Figure 4 gives examples of Raman spectra for
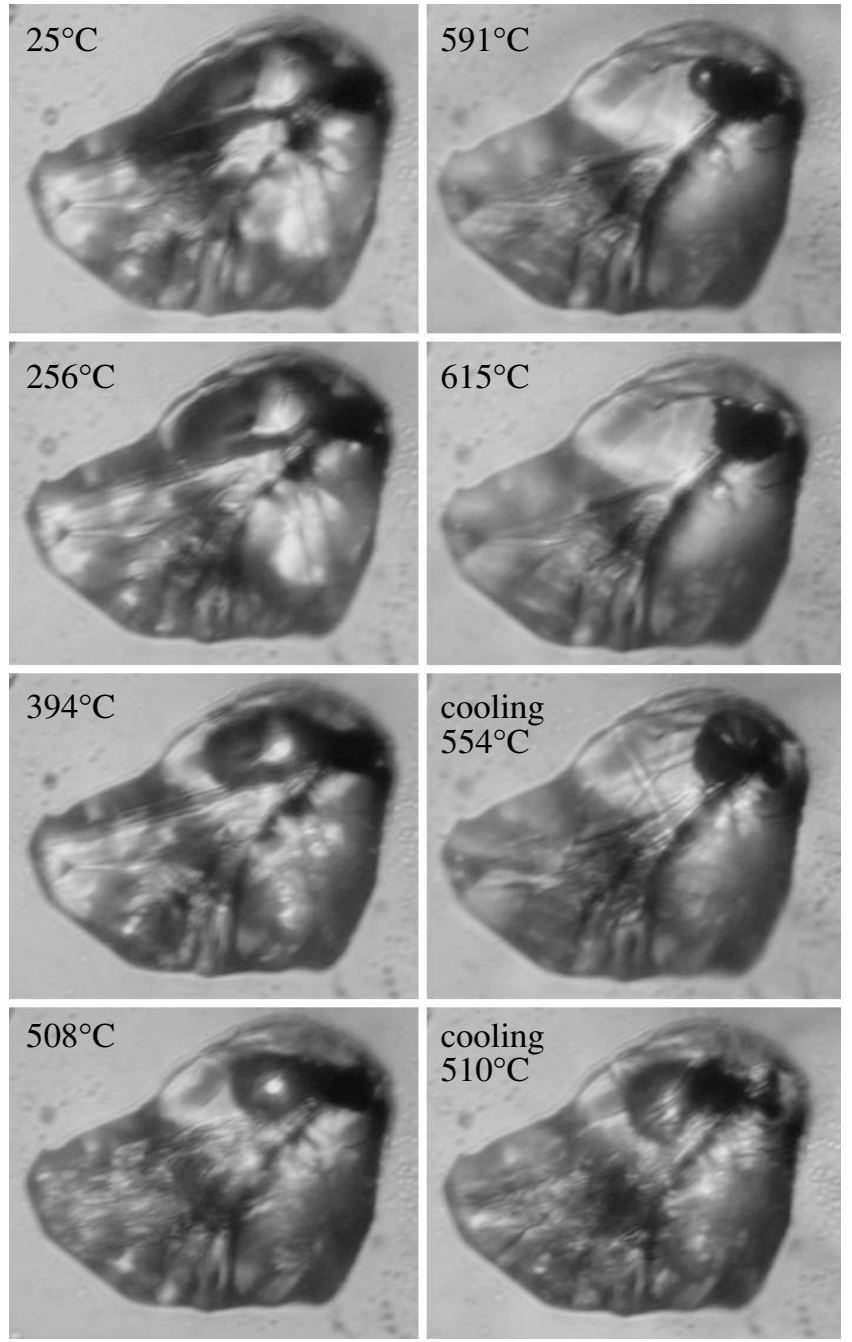

Fig. 2. Behavior of a polyphase melt inclusion in chrome diopside during heating up to $615^{\circ} \mathrm{C}$ and subsequent cooling.

two sulfate minerals, barite and glauberite. Note that an important advantage of this method is the possibility of analyzing inclusion phases without their exposure on the surface of the host mineral. One of such analyzed inclusions can be seen in Fig. 5. Thenardite, gypsum $\left(\mathrm{CaSO}_{4} \cdot 2 \mathrm{H}_{2} \mathrm{O}\right)$, bloedite $\left[\mathrm{Na}_{2} \mathrm{Mg}\left(\mathrm{SO}_{4}\right)_{2} \cdot 4 \mathrm{H}_{2} \mathrm{O}\right]$, and glauberite were detected in this inclusion. In addition, anhydrite $\left(\mathrm{CaSO}_{4}\right)$, barite $\left(\mathrm{BaSO}_{4}\right)$, celestite $\left(\mathrm{SrSO}_{4}\right)$, polyhalite $\left[\mathrm{K}_{2} \mathrm{Ca}_{2} \mathrm{Mg}\left(\mathrm{SO}_{4}\right)_{4} \cdot 2 \mathrm{H}_{2} \mathrm{O}\right]$, and aluminum sulfate were identified in other inclusions.

Intriguing results were obtained by the Raman spectroscopic analysis of the gas phase from inclusions in chrome diopside. Hydrogen and water were detected in all of the analyzed inclusions (11), whereas $\mathrm{CO}_{2}$ and $\mathrm{N}_{2}$ occurred only in trace amounts $(<0.005$ mol \%). Figure 6 illustrates a positive correlation between the integrated intensity of hydrogen spectrum in the gas phase from inclusions in chrome diopside and time. The point labeled "reverse" in the diagram was obtained after $600 \mathrm{~s}$ of measurement of the $\mathrm{H}_{2}$ spec- 
Table 2. Chemical compositions (wt \%) of daughter minerals from silicate-sulfate inclusions in the chrome diopside of the Inagli deposit

\begin{tabular}{|c|c|c|c|c|c|c|c|c|c|c|c|c|c|c|c|}
\hline $\begin{array}{c}\text { Compo- } \\
\text { nent }\end{array}$ & 1 & 2 & 3 & 4 & 5 & 6 & 7 & 8 & 9 & 10 & 11 & 12 & 13 & 14 & 15 \\
\hline $\mathrm{SiO}_{2}$ & 65.27 & 65.05 & 64.08 & 64.18 & 43.03 & 42.93 & 41.84 & 42.40 & 40.96 & 45.69 & 40.72 & 56.13 & 55.36 & 56.83 & 54.56 \\
\hline $\mathrm{TiO}_{2}$ & 0.01 & 0.00 & 0.03 & 0.00 & 1.30 & 0.61 & 0.02 & 1.10 & 0.55 & 0.60 & 0.77 & 0.03 & 0.06 & 0.00 & 0.09 \\
\hline $\mathrm{Al}_{2} \mathrm{O}_{3}$ & 17.01 & 17.19 & 18.87 & 19.03 & 11.48 & 11.28 & 10.65 & 12.11 & 12.52 & 13.83 & 12.21 & 0.12 & 0.03 & 0.04 & 0.00 \\
\hline $\mathrm{Cr}_{2} \mathrm{O}_{3}$ & - & - & - & - & 0.24 & 0.43 & 0.19 & 0.03 & 0.53 & 0.32 & 0.43 & - & - & - & - \\
\hline $\mathrm{FeO}$ & 0.08 & 0.30 & 0.14 & 0.06 & 5.98 & 6.20 & 7.54 & 8.81 & 2.04 & 4.58 & 6.64 & 0.28 & 0.12 & 0.17 & 0.06 \\
\hline $\mathrm{MnO}$ & 0.02 & 0.00 & 0.00 & 0.02 & 0.09 & 0.11 & 0.18 & 0.13 & 0.03 & 0.07 & 0.19 & 0.13 & 0.10 & 0.19 & 0.12 \\
\hline $\mathrm{MgO}$ & 0.08 & 0.10 & 0.01 & 0.00 & 22.63 & 23.13 & 23.90 & 18.86 & 26.33 & 17.12 & 22.66 & 0.39 & 0.16 & 0.32 & 0.05 \\
\hline $\mathrm{CaO}$ & 0.30 & 0.07 & 0.09 & 0.09 & 0.30 & 0.17 & 0.23 & 0.31 & 0.13 & 0.14 & 0.09 & 31.93 & 32.79 & 32.94 & 34.67 \\
\hline $\mathrm{BaO}$ & - & - & - & - & 0.06 & 0.07 & 0.01 & 0.22 & 0.40 & 0.68 & 0.51 & - & - & - & - \\
\hline $\mathrm{Na}_{2} \mathrm{O}$ & 0.05 & 0.07 & 0.03 & 0.04 & 0.07 & 0.06 & 0.08 & 0.11 & 0.07 & 0.10 & 0.04 & 9.22 & 9.18 & 9.31 & 8.54 \\
\hline $\mathrm{K}_{2} \mathrm{O}$ & 17.23 & 17.03 & 16.56 & 16.42 & 11.24 & 11.19 & 10.92 & 10.99 & 10.89 & 11.47 & 10.28 & 0.18 & 0.04 & 0.03 & 0.01 \\
\hline $\mathrm{P}_{2} \mathrm{O}_{5}$ & 0.11 & 0.15 & - & - & 0.15 & 0.16 & 0.13 & 0.07 & - & - & - & 0.17 & 0.23 & 0.08 & - \\
\hline $\mathrm{SO}_{3}$ & 0.00 & 0.00 & 0.00 & 0.02 & 0.07 & 0.05 & 0.05 & 0.10 & 0.35 & 0.05 & 0.08 & 0.00 & 0.00 & 0.00 & 0.00 \\
\hline $\mathrm{Cl}$ & 0.00 & 0.00 & 0.05 & 0.00 & 0.01 & 0.00 & 0.12 & 0.02 & 0.05 & 0.09 & 0.03 & 0.03 & 0.02 & 0.01 & 0.00 \\
\hline $\mathrm{F}$ & - & - & - & - & 0.24 & 0.22 & 0.17 & 0.20 & 0.15 & 0.18 & 0.22 & - & - & - & - \\
\hline Total & 100.16 & 99.94 & 99.86 & 99.86 & 96.89 & 96.61 & 96.03 & 95.46 & 95.00 & 94.92 & 94.87 & 98.61 & 98.09 & 99.92 & 98.10 \\
\hline
\end{tabular}

Note: (1-4) Potassium feldspar, (5-11) phlogopite, and (12-15) pectolite; dashes denote not analyzed.

trum. These results indicate that the hydrogen was not generated under the influence of the laser beam but was a real component of the inclusions.

The composition of melt from which the chrome diopside crystallized was calculated from the visually estimated volume relationships and occurrence frequency of daughter minerals in the inclusions and the microprobe analyses of these minerals. The following volume proportions of phases in the inclusions were accepted: $33 \%$ potassium feldspar, $33 \%$ pectolite, $10 \%$ phlogopite, $10 \%$ chrome diopside, $3 \%$ apatite, $3 \%$ sulfates, and $8 \%$ fluid phase. The estimated melt composition is given in Table 4. This melt contains $53.5 \mathrm{wt} \%$ $\mathrm{SiO}_{2}$; is rich in $\mathrm{CaO}$ (16.3 wt \%), $\mathrm{K}_{2} \mathrm{O}$ (7.9 wt \%), $\mathrm{Na}_{2} \mathrm{O}$
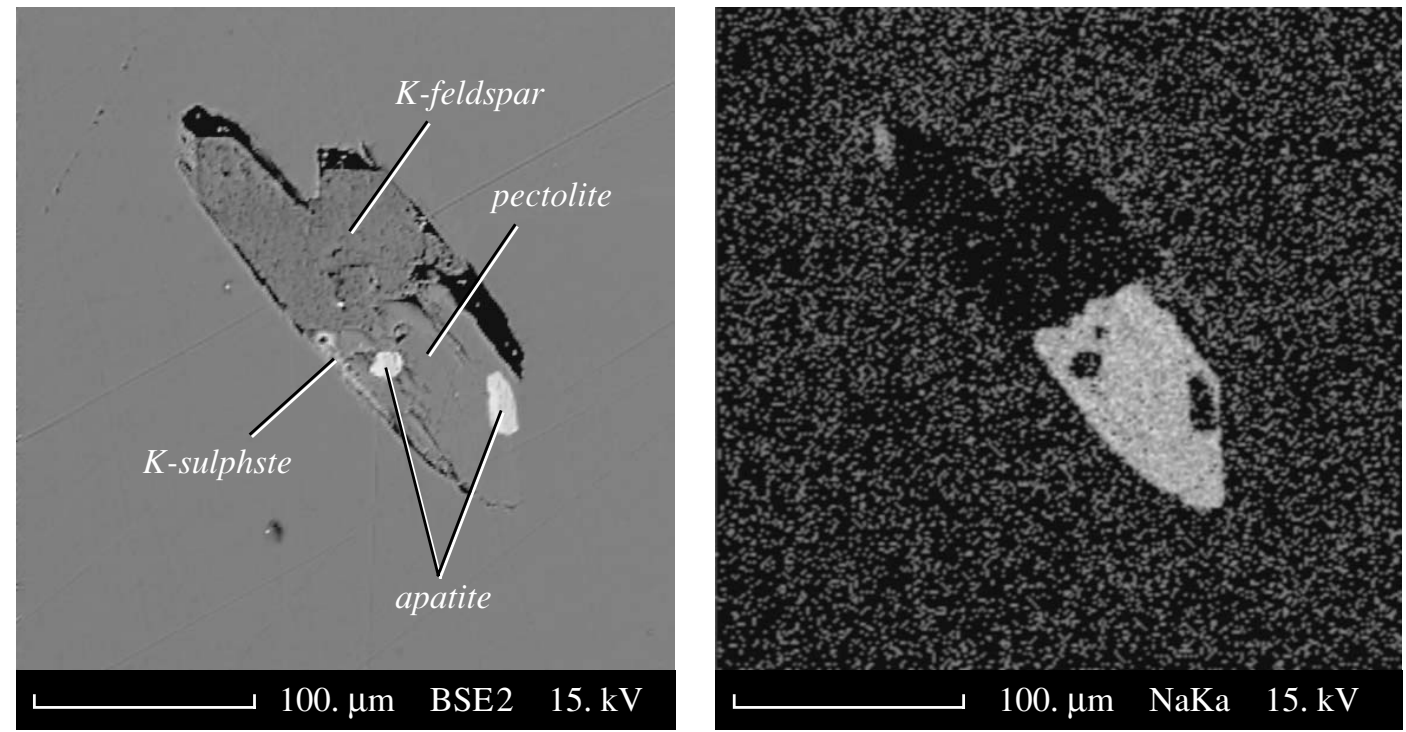

Fig. 3. Melt inclusion exposed on the surface of chrome diopside for microprobe analysis. The left panel is the back-scattered electron image of the inclusions, and the right panel shows the distribution of $\mathrm{NaK} \alpha$. 
Table 3. Chemical compositions (wt \%) of daughter minerals from silicate-sulfate inclusions in the chrome diopside of the Inagli deposit

\begin{tabular}{l|c|c|c|c|c|c|c|c|c|c|c|c|c|c|c}
\hline $\begin{array}{c}\text { Compo- } \\
\text { nent }\end{array}$ & 1 & 2 & 3 & 4 & 5 & 6 & 7 & 8 & 9 & 10 & 11 & 12 & 13 & 14 & 15 \\
\hline $\mathrm{SiO}_{2}$ & 0.42 & 0.15 & 0.90 & 0.07 & 0.03 & 0.48 & 0.71 & 0.64 & 0.13 & 0.16 & 0.60 & 0.18 & 11.37 & 17.17 & 6.71 \\
$\mathrm{TiO}_{2}$ & 0.02 & 0.00 & 0.00 & 0.04 & 0.00 & 0.00 & 0.00 & 0.00 & 0.00 & 0.00 & 0.00 & 0.00 & 0.03 & 0.16 & 0.09 \\
$\mathrm{Al}_{2} \mathrm{O}_{3}$ & 0.01 & 0.08 & 0.36 & 0.00 & 0.00 & 0.06 & 0.01 & 0.02 & 0.00 & 0.08 & 0.06 & 0.00 & 0.07 & 0.30 & 2.58 \\
$\mathrm{FeO}$ & 0.03 & 0.08 & 0.04 & 0.07 & 0.03 & 0.06 & 0.03 & 0.09 & 0.10 & 0.00 & 0.03 & 0.04 & 1.85 & 0.06 & 0.29 \\
$\mathrm{MnO}$ & 0.00 & 0.04 & 0.03 & 0.00 & 0.02 & 0.02 & 0.03 & 0.00 & 0.00 & 0.00 & 0.01 & 0.00 & 0.03 & 0.00 & 0.04 \\
$\mathrm{MgO}$ & 0.19 & 0.12 & 0.28 & 0.07 & 0.02 & 0.11 & 0.00 & 0.00 & 0.01 & 0.04 & 0.00 & 0.00 & 2.44 & 8.54 & 0.58 \\
$\mathrm{CaO}$ & 0.38 & 0.21 & 0.49 & 0.07 & 0.00 & 0.15 & 46.94 & 43.13 & 0.11 & 0.10 & 9.26 & 37.07 & 4.85 & 1.93 & 2.36 \\
$\mathrm{Na} \mathrm{O}_{2} \mathrm{O}$ & 11.47 & 11.79 & 11.87 & 9.58 & 10.23 & 11.66 & 0.09 & 0.10 & 0.01 & 32.16 & 40.18 & 11.17 & 6.35 & 11.22 & 1.69 \\
$\mathrm{~K}_{2} \mathrm{O}$ & 45.19 & 45.70 & 41.14 & 41.99 & 43.50 & 36.80 & 0.01 & 0.07 & 46.98 & 1.97 & 0.55 & 0.21 & 4.75 & 17.57 & 12.59 \\
$\mathrm{P}_{2} \mathrm{O}_{5}$ & 0.03 & 0.12 & 0.13 & - & - & - & 40.15 & 38.70 & - & - & 0.28 & - & 0.21 & 0.16 & 0.21 \\
$\mathrm{SO}_{3}$ & 40.90 & 41.55 & 40.02 & 45.15 & 40.56 & 42.71 & 0.00 & 0.00 & 44.83 & 49.31 & 40.42 & 46.23 & 8.75 & 11.19 & 6.35 \\
$\mathrm{Cl}$ & 0.02 & 0.00 & 0.02 & 0.04 & 0.05 & 0.26 & 0.00 & 0.00 & 0.03 & 0.03 & 0.05 & 0.15 & 10.32 & 1.13 & 0.93 \\
$\mathrm{~F}$ & - & - & - & - & - & - & 2.96 & 2.88 & - & - & - & - & - & - & - \\
$\mathrm{Total}$ & 98.66 & 99.84 & 95.28 & 97.08 & 94.44 & 92.31 & $99.62 *$ & $98.53 * *$ & 92.20 & 83.85 & 91.44 & 95.05 & 50.99 & 69.43 & 34.42 \\
\hline
\end{tabular}

Note: (1-6) Glaserite (synonym to aphthitalite); $(7,8)$ apatite (* total includes $8.28 \mathrm{wt} \% \mathrm{SrO}$ and $0.41 \mathrm{wt} \% \mathrm{BaO}$; ** total includes $12.74 \mathrm{wt} \%$ $\mathrm{SrO}$ and 0.16 wt \% BaO); (9) arcanite; (10) thenardite; (11) glauberite; (12) Ca-Na sulfate; and (13-15) mixture of silicate, sulfate, and chloride minerals. Dashes denote not analyzed.

(3.5 wt \%), and $\mathrm{SO}_{3}(1.4 \mathrm{wt} \%)$; and shows moderate contents of $\mathrm{Al}_{2} \mathrm{O}_{3}(7.5 \mathrm{wt} \%)$ and $\mathrm{MgO}(5.8 \mathrm{wt} \%)$ and low $\mathrm{FeO}$ content $(1.1 \mathrm{wt} \%)$. The contents of volatiles in the melt are also not high, 0.75 wt $\% \mathrm{H}_{2} \mathrm{O}, 0.11 \mathrm{wt} \% \mathrm{~F}$, and 0.03 wt $\% \mathrm{Cl}$. The melt contains 0.13 wt $\% \mathrm{Cr}_{2} \mathrm{O}_{3}$, 0.37 wt $\% \mathrm{SrO}$, and 0.13 wt $\% \mathrm{BaO}$.

Using the accepted proportions of daughter minerals in the inclusions and the densities of these minerals from handbooks, the density of silicate melt from which the chrome diopside crystallized can be approximately estimated. The obtained value is $2.6 \mathrm{~g} / \mathrm{cm}^{3}$. In the same manner, the density of polyphase inclusions containing only sulfate minerals, aqueous solution, and a gas phase was estimated. These calculations accounted for the varying occurrence frequency of different sulfate minerals. The density of these inclusions appeared to be slightly lower, $2.5 \mathrm{~g} / \mathrm{cm}^{3}$.

\section{DISCUSSION}

Hydrogen was identified previously in the gas phase of fluid inclusions by Raman spectroscopy [7]. However, it should be pointed out that among the 135 available publications that presented Raman spectroscopic analyses of the gas phase of fluid inclusions, the presence of hydrogen in the fluid was reported only in seven papers. For instance, $3.2 \mathrm{~mol} \% \mathrm{H}_{2}$ were obtained for a fluid inclusion in chkalovite from the alkaline igneous complex of the Gardar province, South Greenland [8].
In addition to hydrogen, this inclusion contained $\mathrm{CH}_{4}$ $(94.7 \mathrm{~mol} \mathrm{\%})$ and $\mathrm{C}_{2} \mathrm{H}_{6}(2.1 \mathrm{~mol} \%)$. Minor amounts of hydrogen were also determined in fluid inclusions from minerals of metamorphic rocks: $0.03-0.21 \mathrm{~mol} \%$ in quartz from North Wales [9] and 0.3-3.0 mol \% in diopside from the Sondrio region, Italy [10]. The Raman spectroscopy of fluid inclusions was used together with gas chromatography for the investigation of the Dachang tin-base metal ore field, China [11]. The analysis of volatiles from the gas phase of an inclusion in garnet from skarns showed the following molar

Table 4. Calculated composition of the melt from which chrome diopside crystallized

\begin{tabular}{l|r||l|r}
\hline Component & wt \% & Component & wt \% \\
\hline $\mathrm{SiO}_{2}$ & 53.53 & $\mathrm{BaO}$ & 0.13 \\
$\mathrm{TiO}_{2}$ & 0.13 & $\mathrm{Na}_{2} \mathrm{O}$ & 3.49 \\
$\mathrm{Al}_{2} \mathrm{O}_{3}$ & 7.45 & $\mathrm{~K}_{2} \mathrm{O}$ & 7.87 \\
$\mathrm{Cr}_{2} \mathrm{O}_{3}$ & 0.13 & $\mathrm{P}_{2} \mathrm{O}_{5}$ & 1.38 \\
$\mathrm{FeO}$ & 1.07 & $\mathrm{SO}_{3}$ & 1.41 \\
$\mathrm{MnO}$ & 0.06 & $\mathrm{Cl}$ & 0.03 \\
$\mathrm{MgO}$ & 5.81 & $\mathrm{~F}$ & 0.11 \\
$\mathrm{CaO}$ & 16.28 & $\mathrm{H}_{2} \mathrm{O}$ & 0.75 \\
$\mathrm{SrO}$ & 0.37 & Total & 100.00 \\
\hline
\end{tabular}




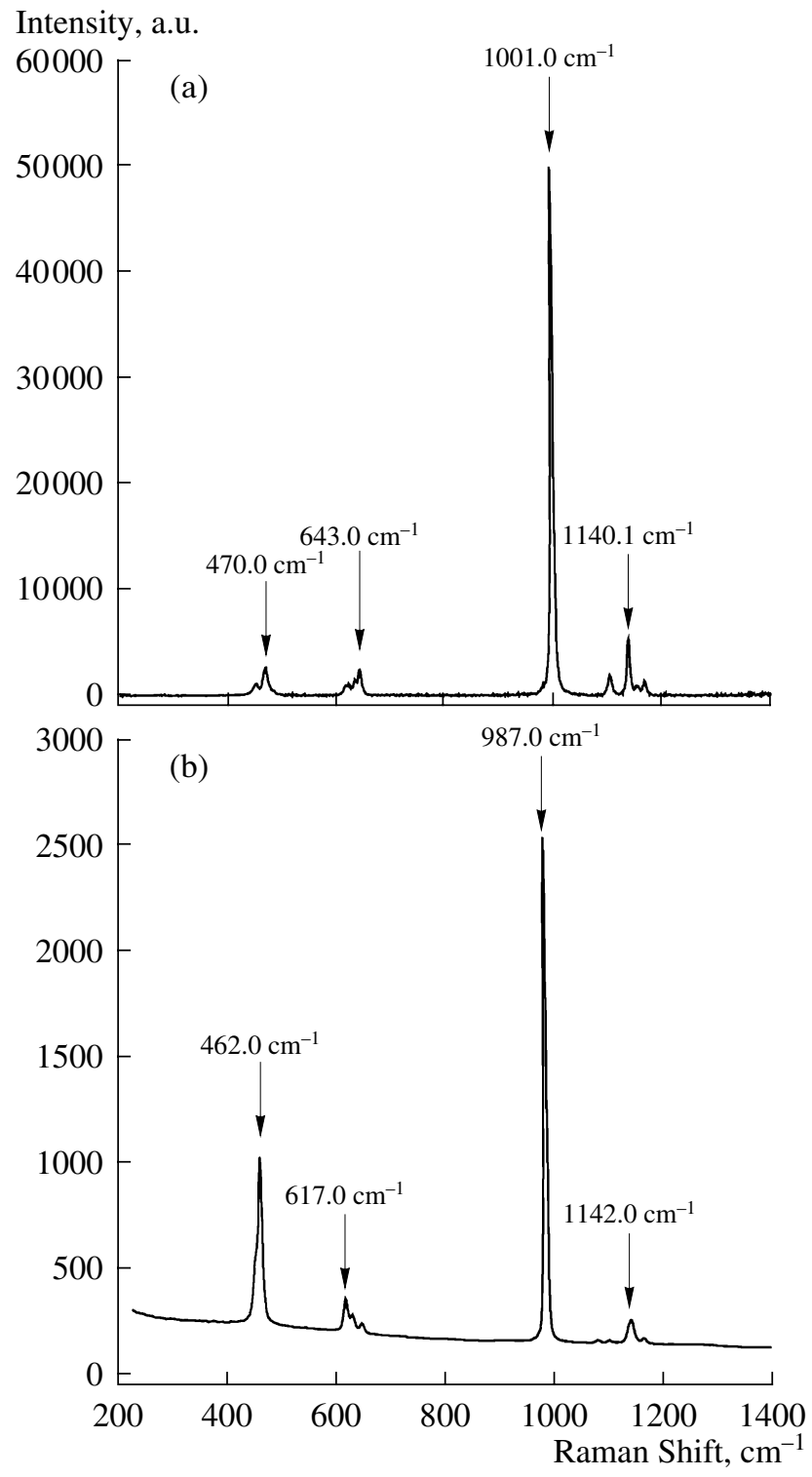

Fig. 4. Raman spectra of (a) glauberite and (b) barite.

percentages: $2.1 \mathrm{H}_{2}, 10.0 \mathrm{CO}_{2}$, and $87.9 \mathrm{CH}_{4}$. The temperatures of formation of the skarn minerals were 450$600^{\circ} \mathrm{C}$. Primary low-temperature $\left(130-160^{\circ} \mathrm{C}\right)$ fluid inclusions with hydrogen in the gas phase were found in late fluorite from the pegmatite veins of the Arkaroola region, southern Australia [12]. Higher hydrogen contents (up to $100 \mathrm{~mol} \%$ ) were observed in many fluid inclusions in quartz from the Precambrian hydrothermal uranium deposits of Oklo in Gabon and Rabbit Lake, Cluff Lake [13], and McArthur [14] in Canada.

The occurrence of hydrogen in the composition of fluid inclusions in hydrothermal minerals is considered as a nontrivial phenomenon. On the other hand, the computer modeling of the chemical characteristics of the aqueous phase of thermodynamically closed waterrock systems (granite, syenite, diorite, basalt, and dun-

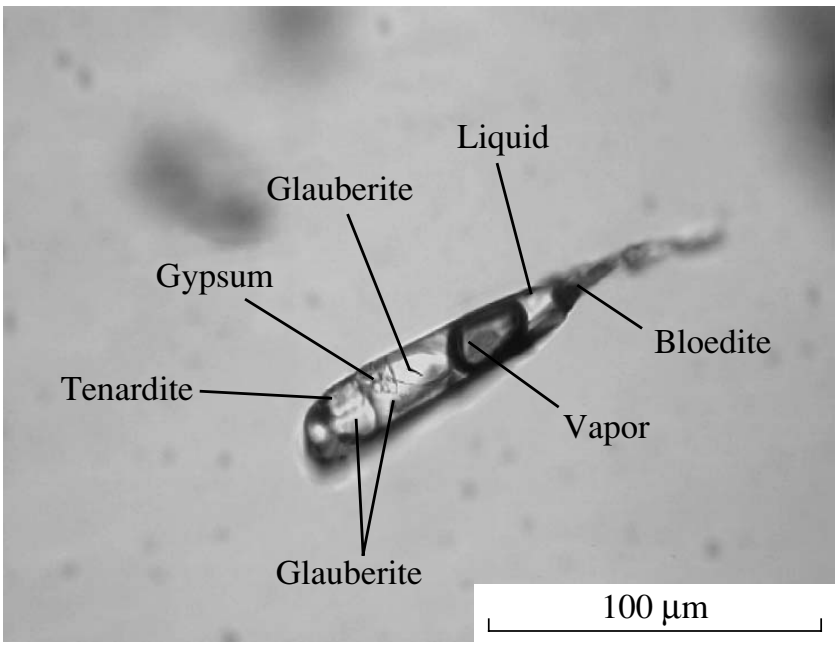

Fig. 5. Inclusion of sulfate melt with daughter phases identified by Raman spectroscopy.

ite of ordinary compositions) showed [15] that the aqueous solution in equilibrium with mafic-ultramafic rocks has substantially reduced characteristics, and the equilibrium fugacity of $\mathrm{H}_{2}$ is higher than 0.1 bar. The results of computer modeling were confirmed by experiments [16].

The seemingly contradictory combination of the high partial pressure of $\mathrm{H}_{2}(\mathrm{~g})$ and the sulfate form of sulfur occurrence in the high-temperature water-salt fluid, which was established by the investigation of polyphase inclusions in chrome diopside, is not an accidental determination but rather an inherent property of the water-rock system. This can be seen from the results of thermodynamic calculations for the waterbasic rock system at $800^{\circ} \mathrm{C}$ and $2 \mathrm{kbar}$ (Fig. 7). When $\mathrm{H}_{2}(\mathrm{~g})$ fugacity is lower than $0.3 \mathrm{bar}$, sulfate species are dominant in the aqueous fluid. Consequently, the reducing properties of high-temperature aqueous fluids and the presence of sulfate minerals are the normal state of the water-rock system under the elevated parameters of hydrothermal mineral formation.

Sulfate daughter minerals are not rare in melt and fluid inclusions [17-31]. Nesbitt and Kelly [17] investigated inclusions in minerals of the Magnet Cove carbonatites (Arkansas, United States) and, in addition to chlorides and carbonates, detected a number of sulfates in them: arcanite, thenardite, gypsum, glauberite, celestite, barite, $\mathrm{Fe}-\mathrm{Cu}$ sulfate, and syngenite $\left[\mathrm{K}_{2} \mathrm{Ca}\left(\mathrm{SO}_{4}\right)_{2} \cdot \mathrm{H}_{2} \mathrm{O}\right]$. The scanning electron microscopy of polyphase inclusions in quartz from the Santa Rita porphyry copper deposit (New Mexico, United States) revealed daughter crystals of anhydrite, halite, chalcopyrite, potassium feldspar, muscovite, and iron-rich mica [18].

Numerous primary inclusions were observed in apatite crystals from the region of the Mushugai Khuduk carbonatite complex (Mongolia). Their investigation revealed the existence of natural high-temperature 
$\left(1240-1290^{\circ} \mathrm{C}\right)$ phosphate-sulfate melts [19]. The main minerals of these inclusions are anhydrite and apatite. During subsequent investigations, magmatic celestite was found in melt inclusions in apatite from this carbonatite complex [20]. These inclusions homogenized at $1225^{\circ} \mathrm{C}$. It was shown that lower temperature $\left(670^{\circ} \mathrm{C}\right)$ salt melt inclusions in fluorite from the celestite-fluorite rocks of the complex contain numerous sulfate minerals: $\mathrm{Na}-\mathrm{Ca}$ sulfate, strontian barite, $\mathrm{Sr}-\mathrm{Na}-\mathrm{Ca}$ sulfate, and $\mathrm{Ba}-\mathrm{K}-\mathrm{Sr}$ sulfate [21].

Magmatic salt inclusions were found in minerals from the alkaline basaltoids of the eastern Pamirs [22]. Polyphase inclusions in fluorite contain 90-95 vol \% daughter crystals, the most abundant among which $(>50 \%)$ is bassanite (hydrous calcium sulfate, $\mathrm{CaSO}_{4} \cdot 0.5 \mathrm{H}_{2} \mathrm{O}$ ). These inclusions were completely homogenized at $680-740^{\circ} \mathrm{C}$. K-Na sulfate (aphthitalite, a synonym for glaserite) was identified in high-temperature $\left(400-700^{\circ} \mathrm{C}\right)$ fluid inclusions in quartz from the Eikeren-Skrim granite complex in Norway [23].

Fluid inclusions in potassium feldspar from the syenite xenoliths in the trachytes of Ponza Island (Pontine Archipelago, Italy) were investigated by Belkin et al. [24]. Using scanning electron microscopy, they identified several daughter sulfate minerals: glauberite, arcanite, anhydrite, and thenardite, as well as chlorides: halite and sylvite. These inclusions were completely homogenized between 640 and $755^{\circ} \mathrm{C}$. Several authors reported the occurrence of sulfates among the skarn minerals of the Vesuvius volcanic complex, Italy [25-27]. Sulfate minerals (glaserite, arcanite, and anhydrite) were found together with chlorides, carbonates, and opaque minerals (sulfides or oxides) among the daughter phases of polyphase inclusions in nepheline and clinopyroxene of skarns from the border zone of the igneous complex [25]. Such multicomponent salt melt existed at high temperatures, between 700 and $800^{\circ} \mathrm{C}$. Gilg et al. [26] and Fulignati et al. [27] also studied fluid inclusions in minerals from Vesuvius skarns. Salt melt inclusions were described in wollastonite, gehlenite, scapolite, and clinopyroxene. In addition to sulfates, the inclusions contain daughter crystals of sylvite, halite, calcite, apatite, fluorite, biotite, and phlogopite. The sulfate minerals are arcanite, anhydrite, syngenite, glauberite, aphthitalite, and matteuccite $\left(\mathrm{NaHSO}_{4} \cdot \mathrm{H}_{2} \mathrm{O}\right)$. High homogenization temperatures of $870-890^{\circ} \mathrm{C}$ were reported for these salt melt inclusions of chloride-carbonate-sulfate-fluoride-silicate composition.

A marvelous photomicrograph of a silicate-salt inclusion in clinopyroxene from mafic xenoliths of Ventotene Island (Italy) was presented by De Vivo et al. [28]. This inclusion contained silicate glass (8.9 wt \% $\mathrm{K}_{2} \mathrm{O}, 0.93$ wt $\% \mathrm{P}_{2} \mathrm{O}_{5}$, and 0.45 wt $\% \mathrm{~S}$ ), Cu-bearing iron sulfide, a $\mathrm{CO}_{2}$-bearing gas phase, and a salt globule consisting of a number of crystals, among which carbonates (including calcite) and sulfates (including barite) were identified.

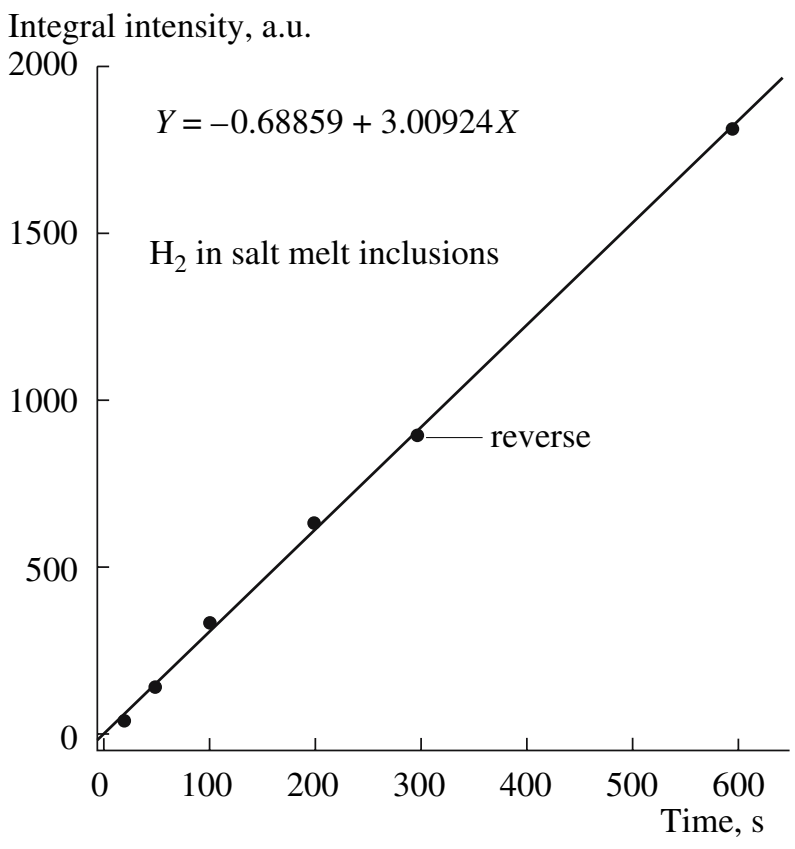

Fig. 6. Correlation of the integral intensity of the hydrogen spectrum with time for the gas phase of inclusions in chrome diopside. The point labeled "reverse" was obtained after the measurement of the intensity of the $\mathrm{H}_{2}$ spectrum for $600 \mathrm{~s}$.

Alkaline calcium-rich sulfate-carbonate melt inclusions were observed in the melilite-monticellite-olivine rocks of the Malyi Murun alkaline massif (Aldan, Russia) by Panina and Usol'tseva [29, 30]. These authors calculated the normative compositions of the inclusions and showed that they contained the following sulfates: $\mathrm{Na}_{2} \mathrm{SO}_{4}, \mathrm{~K}_{2} \mathrm{SO}_{4}, \mathrm{CaSO}_{4}$, and $\mathrm{BaSO}_{4}$.

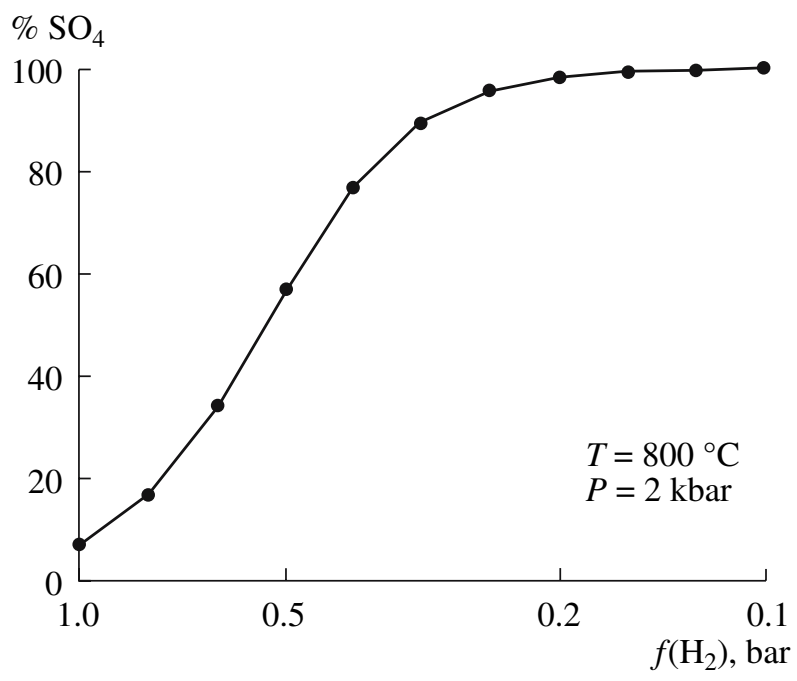

Fig. 7. Fraction of sulfate sulfur species in the aqueous phase of the water-basic rock system at $800^{\circ} \mathrm{C}$ and $2 \mathrm{kbar}$ as a function of redox potential. 
Homogenization temperatures of $1060-1190^{\circ} \mathrm{C}$ were reported for these inclusions.

In the past few years, findings of sulfate minerals as daughter phases in inclusions were reported by several authors [12, 31, 32]. Anhydrite was identified by Raman spectroscopy in melt inclusion in diopside from the diopside-titanite pegmatite veins of the Arkaroola region, southern Australia [12]. Numerous sulfates of $\mathrm{Ca}, \mathrm{Na}, \mathrm{K}, \mathrm{Sr}$, and $\mathrm{Ba}$ (anhydrite, barytocelestite, celestite, thenardite, arcanite, and aphthitalite) were identified in melt inclusions in aegirine-diopside and titanite from the carbonatites and shonkinites of southwestern Transbaikalia [31]. These inclusions were homogenized at $1000^{\circ} \mathrm{C}$. Kamenetsky et al. [32] studied in detail extremely fresh essentially anhydrous $(<0.5 \mathrm{wt} \%$ $\mathrm{H}_{2} \mathrm{O}$ ) kimberlite samples from the Udachnaya East pipe (Siberia, Russia). In addition to apatite, silicates (phlogopite), carbonates, and chlorides, they identified various sulfate minerals (aphthitalite, $\mathrm{Ba}-, \mathrm{Ca}-, \mathrm{Sr}-\mathrm{Ca}-\mathrm{Ba}$, and $\mathrm{Na}-\mathrm{Ca}$ sulfates) in shortite and in the rock groundmass.

It should be noted that sulfate minerals in inclusions in various minerals were mostly discovered during the investigation of alkaline mafic magmas or carbonatites. Essentially chloride salt melts are more common in magmas of silicic compositions [e.g., 33-39]. One of the first published descriptions of such melts was that of Roedder and Coombs [33]. They studied melt and fluid inclusions in quartz from the granitic rocks of Ascension Island and demonstrated the existence of immiscibility between chloride and silicate melts. Subsequently, the phenomena of silicate-chloride melt immiscibility were reported from other complexes of various regions [e.g., 34-39].

Coexisting silicate and chloride melts were observed during thermometric experiments with inclusions in quartz from the granitoids of the Mariktikan pluton (Buryatia, Russia) [34]. These authors presented photomicrographs of such inclusions with two immiscible melts at $980^{\circ} \mathrm{C}$. It was also noted that such inclusions were observed only in the central part of the massif, where they occur in quartz crystals from miarolitic cavities and in rock-forming quartz from granites near such cavities.

Melt inclusions of two different compositions, silicate and chloride, were found in quartz from the granite porphyries of the Priangrenskii district of the Kurama Mountains (Uzbekistan) [36]. The silicate melt inclusions were homogenized at $780-950^{\circ} \mathrm{C}$, and their quenching produced a homogeneous silicic glass (73.6 wt $\% \mathrm{SiO}_{2}$ and 4.4 wt $\% \mathrm{~K}_{2} \mathrm{O}$ ) with high contents of $\mathrm{Cl}(0.33 \mathrm{wt} \%)$ and $\mathrm{F}(0.42 \mathrm{wt} \%)$. The chloride melt inclusions are most common in quartz and were homogenized at high temperatures from 680 to $820^{\circ} \mathrm{C}$. Their qualitative microprobe analysis showed the prevalence of $\mathrm{Na}$ and $\mathrm{Cl}$; the presence of $\mathrm{K}, \mathrm{Fe}$, and $\mathrm{Mn}$; and negligible amounts of $\mathrm{Mg}, \mathrm{Ti}, \mathrm{Ca}$, and $\mathrm{F}$.
Similar high-temperature silicate and chloride melts were investigated in quartz from the Mount Genis granites (southeastern Sardinia, Italy) [37] and in quartz from the pantellerites of the Island of Pantelleria (Italy) [38].

Among the most recent contributions are our studies of the Industrial'noe tin deposit in northeastern Russia $[39,40]$. The investigation of inclusions showed that magmatic silicate melts $\left(73.2 \mathrm{wt} \% \mathrm{SiO}_{2}, 3.1\right.$ wt $\%$ $\mathrm{Na}_{2} \mathrm{O}$, and 4.5 wt $\% \mathrm{~K}_{2} \mathrm{O}$ ) associated with globules of chloride melts during the crystallization of quartz in the granites. The silicate melt $\left(760-1020^{\circ} \mathrm{C}\right)$ showed elevated $\mathrm{Cl}$ contents (up to $0.51 \mathrm{wt} \%$ and $0.31 \mathrm{wt} \%$ on average for 12 analyses). Using a proton microprobe (PIXE), the distribution and contents of a number of elements were determined in polyphase salt globules, which were found in quartz from granites and from a mineralized miarolitic cavity in them. The analysis of salt globules in quartz from both the granites ( 8 analyses) and the miarolitic cavity (29 analyses) revealed high average contents (wt \%) of $\mathrm{Cl}$ (27.5-25.0), $\mathrm{Fe}$ (9.7-5.4), Mn (1.1-1.0), Cu (7.2), Zn (0.66-0.50), $\mathrm{Pb}(0.37-0.24)$, and some trace elements, including (average, ppm) Rb (1850-810), As (2020), Sr (1090), $\mathrm{Br}$ (990-470), and Sn (540).

\section{CONCLUSIONS}

(1) Primary and primary-secondary polyphase inclusions were investigated in chrome diopside from the Inagli gemstone deposit. The compositions of daughter crystalline phases from inclusions were determined. They are dominated by sulfate minerals: glaserite, glauberite, anhydrite, gypsum, barite, bloedite, thenardite, polyhalite, arcanite, aluminum sulfate, and celestite. Among the silicate minerals, potassium feldspar, pectolite, and phlogopite were identified. It was concluded that the chrome diopside crystallized from a silicate melt (with a density of $\sim 2.6 \mathrm{~g} / \mathrm{cm}^{3}$ ), which contained the emulsion of less dense $\left(\sim 2.5 \mathrm{~g} / \mathrm{cm}^{3}\right)$ salt globules of sulfate-dominated compositions.

(2) The composition of the parental melt of chrome diopside was calculated. This melt $\left(53.5 \mathrm{wt} \% \mathrm{SiO}_{2}\right)$ showed high contents of $\mathrm{CaO}(16.3 \mathrm{wt} \%), \mathrm{K}_{2} \mathrm{O}(7.9 \mathrm{wt} \%)$, $\mathrm{Na}_{2} \mathrm{O}(3.5 \mathrm{wt} \%)$, and $\mathrm{SO}_{3}(1.4 \mathrm{wt} \%)$; relatively minor contents of $\mathrm{Al}_{2} \mathrm{O}_{3}(7.5 \mathrm{wt} \%)$ and $\mathrm{MgO}(5.8 \mathrm{wt} \%)$; and low $\mathrm{FeO}(1.1 \mathrm{wt} \%)$. The contents of volatile components in the melt were also rather low: $0.75 \mathrm{wt} \% \mathrm{H}_{2} \mathrm{O}$, 0.11 wt $\% \mathrm{~F}$, and 0.03 wt $\% \mathrm{Cl}$. The melt contained 0.13 wt $\% \mathrm{Cr}_{2} \mathrm{O}_{3}, 0.37$ wt $\% \mathrm{SrO}$, and 0.13 wt $\% \mathrm{BaO}$.

(3) The Raman spectroscopy of the gas phase of the inclusions indicated the presence of hydrogen. Thermodynamic calculations for the water-basic rock system at $800^{\circ} \mathrm{C}$ and $2 \mathrm{kbar}$ suggest that sulfate species are predominant in aqueous fluid at an $\mathrm{H}_{2}(\mathrm{~g})$ fugacity of less than 0.3 bar.

(4) The analysis of available published data showed that, in most cases, sulfate daughter phases in inclusions in various minerals were found during the inves- 
tigation of alkaline mafic magmas and carbonatites. Salt melts of chloride-dominated compositions are more common in felsic magmas.

\section{ACKNOWLEDGMENTS}

The authors thank M.S. Myl'nikova, who provided some chrome diopside samples for our investigations. This study was financially supported by the Russian Foundation for Basic Research, project no. 07-0500497.

\section{REFERENCES}

1. A. M. Korchagin, "Inagli Vermiculite-Phlogopite Deposit," Izv. Akad. Nauk SSSR, Ser. Geol., No. 8, 8697 (1966).

2. A. M. Korchagin, "Inagli Alkaline Ultrabasic Massif, Southern Yakutia," Izv. Akad. Nauk SSSR, Ser. Geol., No. 7, 49-59 (1972).

3. A. M. Korchagin, Inagli Pluton and Its Mineral Resources (Nedra, Moscow, 1996) [in Russian].

4. R. A. Oktyabr'skii and A. M. Korchagin, "'Siberian Emerald' (History of Discovery and New Data)," Vestn. Dal'nevost. Otd. Ross. Akad. Nauk, No. 4, 29-36 (2000).

5. V. B. Naumov, V. I. Kovalenko, M. I. Kuz'min, et al., "Thermometric Study of Melt Inclusions in Topaz from Topaz-Bearing Quartz Keratophyres (Ongonites)," Dokl. Akad. Nauk SSSR 199 (3), 681-683 (1971).

6. N. P. Ermakov, "On Primary-Secondary Inclusions in Minerals," Mineral. Sb. L'vovsk. Geol. Ob-va, No. 3, 23-27 (1949).

7. P. Dhamelincourt, J.-M. Beny, J. Dubessy, and B. Poty, "Analyse d'inclusions fluids a la microsonde MOLE a effet Raman,” Bull. Mineral. 102, 600-610 (1979).

8. J. Konnerup-Madsen, J. Dubessy, and J. Rose-Hansen, "Combined Raman Microprobe Spectrometry and Microthermometry of Fluid Inclusions in Minerals from Igneous Rocks of the Gardar Province (South Greenland)," Lithos 18, 271-280 (1985).

9. S. H. Bottrell, L. P. Carr, and J. Dubessy, "A NitrogenRich Metamorphic Fluid and Coexisting Minerals in Slates from North Wales," Mineral. Mag. 52, 451-457 (1988).

10. A. Peretti, J. K. Dubessy, J. Mullis, et al., "Highly Reducing Conditions during Alpine Metamorphism of the Malenco Peridotite (Sondrio, Northern Italy) Indicated by Mineral Paragenesis and $\mathrm{H}_{2}$ in Fluid Inclusions," Contrib. Mineral. Petrol. 112, 329-340 (1992).

11. M. Fu, T. A. P. Kwak, and T. P. Mernagh, "Fluid Inclusion Studies of Zoning in the Dachang Tin-Polymetallic Ore Field, People's Republic of China,” Econ. Geol. 88, 283-300 (1993).

12. R. J. Bakker and M. A. Elburg, "A Magmatic-Hydrothermal Transition in Arkaroola (Northern Flinders Ranges, South Australia): From Diopside-Titanite Pegmatites to Hematite-Quartz Growth," Contrib. Mineral. Petrol. 152, 541-569 (2006).

13. J. Dubessy, M. Pagel, J.-M. Beny, et al., "Radiolysis Evidence by $\mathrm{H}_{2}-\mathrm{O}_{2}$ and $\mathrm{H}_{2}$-Bearing Fluid Inclusions in
Three Uranium Deposits," Geochim. Cosmochim. Acta 52, 1155-1167 (1988).

14. D. Derome, M. Cathelineau, T. Lhomme, and M. Cuney, "Fluid Inclusion Evidence of the Differential Migration of $\mathrm{H}_{2}$ and $\mathrm{O}_{2}$ in the McArthur River Unconformity-Type Uranium Deposit (Saskatchewan, Canada). Possible Role on Post-Ore Modifications of the Host Rocks," J. Geochem. Explor. 78-79, 525-530 (2003).

15. V. L. Barsukov and B. N. Ryzhenko, "Temperature Evolution of Pore Solutions in Equilibrium with Rocks of Various Silica Contents," Geol. Rudn. Mestorozhd., No. 3, 208-226 (2001) [Geol. Ore Dep. 43, 184-201 (2001)].

16. B. N. Ryzhenko and N. I. Kovalenko, "Experimental Determination of the Redox Potential of the Rock-Water System. 2. The Granite-Water System at $400-450^{\circ} \mathrm{C}$ and 1 kbar," Geokhimiya, No. 5, 547-553 (2002) [Geochem. Int. 40, 499-507 (2002)].

17. B. E. Nesbitt and W. C. Kelly, "Magmatic and Hydrothermal Inclusions in Carbonatite of the Magnet Cove Complex, Arkansas," Contrib. Mineral. Petrol. 63, 271294 (1977).

18. E. Y. Anthony, T. J. Reynolds, and R. E. Beane, "Identification of Daughter Minerals in Fluid Inclusions Using Scanning Electron Microscopy and Energy Dispersive Analysis," Am. Mineral. 69, 1053-1057 (1984).

19. V. B. Naumov, I. P. Solovova, V. I. Kovalenko, et al., "Natural Phosphate-Sulfate Melts," Dokl. Akad. Nauk SSSR 300 (3), 672-675 (1988).

20. I. A. Andreeva, V. B. Naumov, V. I. Kovalenko, et al., "Magmatic Celestite in Melt Inclusions in Apatites from the Mushugai-Khuduk Alkaline Volcanoplutonic Complex (Southern Mongolia),” Dokl. Akad. Nauk 337 (4), 499-502 (1994).

21. I. A. Andreeva, V. B. Naumov, V. I. Kovalenko, and N. N. Kononkova, "Fluoride-Sulfate and Chloride-Sulfate Salt Melts of the Carbonatite-Bearing Complex Mushugai-Khuduk, Southern Mongolia," Petrologiya 6 (3), 307-315 (1998) [Petrology 6, 284-292 (1998)].

22. I. P. Solovova, A. V. Girnis, A. V. Guzhova, and V. B. Naumov, "Magmatic Salt Inclusions in Minerals from the Alkali Basalts of the Eastern Pamirs," Geokhimiya, No. 1, 68-77 (1992).

23. T. H. Hansteen and E. A. J. Burke, "Aphthitalite in HighTemperature Fluid Inclusions in Quartz from the Eikeren-Skrim Granite Complex, the Oslo Paleorift," Norsk. Geologisk. Tidsskrift 74 (4), 238-240 (1994).

24. H. E. Belkin, B. De Vivo, A. Lima, and K. Torok, "Magmatic (Silicates/Saline/Sulfur-Rich/ $\mathrm{CO}_{2}$ ) Immiscibility and Zirconium and Rare-Earth Enrichment from Alkaline Magma Chamber Margins: Evidence from Ponza Island, Pontine Archipelago, Italy," Eur. J. Mineral. 8, 1401-1420 (1996).

25. P. Fulignati, V. S. Kamenetsky, P. Marianelli, et al., "Melt Inclusion Record of Immiscibility between Silicate, Hydrosaline, and Carbonate Melts: Applications to Skarn Genesis at Mount Vesuvius," Geology 29 (11), 1043-1046 (2001).

26. H. A. Gilg, A. Lima, R. Somma, et al., "Isotope Geochemistry and Fluid Inclusion Study of Skarns from Vesuvius," Mineral. Petrol. 73, 145-176 (2001). 
27. P. Fulignati, V. S. Kamenetsky, P. Marianelli, and A. Sbrana, "Fluid Inclusion Evidence of Second Immiscibility within Magmatic Fluids (79 AD Eruption of Mt. Vesuvius)," Period. Mineral. 74, 43-54 (2005).

28. B. De Vivo, A. Lima, and J. D. Webster, "Volatiles in Magmatic-Volcanic Systems," Elements 1, 19-24 (2005).

29. L. I. Panina and L. M. Usol'tseva, "Alkaline High-Ca Sulfate-Carbonate Melt Inclusions in Melilite-Monticellite-Olivine Rocks from the Malomurunskii Alkaline Massif, Aldan," Petrologiya 7 (6), 653-669 (1999) [Petrology 7, 610-625 (1999)].

30. L. I. Panina and L. M. Usol'tseva, "Role of Liquid Immiscibility in the Formation of Calcite Carbonatites in the Malomurunskii Massif (Aldan)," Geol. Geofiz. 41 (5), 655-670 (2000).

31. A. G. Doroshkevich and G. S. Ripp, "The Composition of Carbonatite Complexes of Transbaikalia: Data on Study of Inclusions," in Proceedings of IAGOD Conference, Vladivostok, Russia, 2004 (Vladivostok, 2004), pp. 288-291 (2004).

32. V. S. Kamenetsky, M. B. Kamenetsky, V. V. Sharygin, et al., "Chloride and Carbonate Immiscible Liquids at the Closure of the Kimberlite Magma Evolution (Udachnaya-East Kimberlite, Siberia)," Chem. Geol. 237 (3-4), 384-400 (2007).

33. E. Roedder and D. S. Coombs, "Immiscibility in Granitic Melts, Indicated by Fluid Inclusions in Ejected Granitic Blocks from Ascension Island," J. Petrol. 8 (3), 417-451 (1967).
34. F. G. Reyf and E. D. Bazheev, "Magmatogenic Chloride Solutions and Tungsten Mineralization," Geokhimiya, No. 1, 63-70 (1977).

35. V. B. Naumov, V. I. Kovalenko, and L. G. Filimonova, "Immiscibility of Silicate and Salt Melts: Data from the Investigation of Inclusions in Minerals," in Proceedings of 10th Seminar on the Geochemistry of Magmatic Rocks (GEOKhI AN SSSR, Moscow, 1984), pp. 130-131 [in Russian].

36. V. B. Naumov, I. P. Solovova, V. A. Kovalenker, et al., "Crystallization Conditions and Compositions of Silicate and Salt Melts from the Volcanoplutonic Complex of the Priangrenskii Region (Middle Asia)," Dokl. Akad. Nauk SSSR 312 (5), 1227-1230 (1990).

37. M. L. Frezzotti, "Magmatic Immiscibility and Fluid Phase Evolution in the Mount Genis Granite (Southeastern Sardinia, Italy)," Geochim. Cosmochim. Acta 56, 21-33 (1992).

38. J. B. Lowenstern, "Chlorine, Fluid Immiscibility, and Degassing in Peralkaline Magmas from Pantelleria, Italy," Am. Mineral. 79 (3-4), 353-369 (1994).

39. V. S. Kamenetsky, V. B. Naumov, P. Davidson, et al., "Immiscibility between Silicate Magmas and Aqueous Fluids: A Melt Inclusion Pursuit into the MagmaticHydrothermal Transition in the Omsukchan Granite (NE Russia)," Chem. Geol. 210 (1-4), 73-90 (2004).

40. V. B. Naumov and V. S. Kamenetsky, "Silicate and Salt Melts in the Genesis of the Industrial'noe Tin Deposit: Evidence from Inclusions in Minerals," Geokhimiya, No. 12, 1279-1289 (2006) [Geochem. Int. 44, 11811190 (2006)]. 